\title{
Article
}

\section{S-scheme $\mathrm{Sb}_{2} \mathrm{WO}_{6} / \mathrm{g}-\mathrm{C}_{3} \mathrm{~N}_{4}$ photocatalysts with enhanced visible-light-induced photocatalytic NO oxidation performance}

\author{
Yuyu Ren †, Yuan Li ${ }^{\dagger}$, Xiaoyong Wu, Jinlong Wang, Gaoke Zhang * \\ Hubei Key Laboratory of Mineral Resources Processing and Environment, State Key Laboratory of Silicate Materials for Architectures, Wuhan University \\ of Technology, Wuhan 430070, Hubei, China
}

\section{A R T I C L E I N F}

\section{Article history:}

Received 16 March 2020

Accepted 30 April 2020

Published 5 January 2021

\section{Keywords:}

$\mathrm{Sb}_{2} \mathrm{WO}_{6}$

g- $\mathrm{C}_{3} \mathrm{~N}_{4}$

S-scheme photocatalyst

Photocatalytic NO oxidation

In situ DRIFTS

\begin{abstract}
A B S T R A C T
Normal photocatalysts cannot effectively remove low-concentration NO because of the high recombination rate of the photogenerated carriers. To overcome this problem, S-scheme composites have been developed to fabricate photocatalysts. Herein, a novel S-scheme $\mathrm{Sb}_{2} \mathrm{WO}_{6} / g-\mathrm{C}_{3} \mathrm{~N}_{4}$ nanocomposite was fabricated by an ultrasound-assisted method, which exhibited excellent performance for photocatalytic ppb-level NO removal. Compared with the pure constituents of the nanocomposite, the as-prepared $15 \%-\mathrm{Sb}_{2} \mathrm{WO}_{6} / g-\mathrm{C}_{3} \mathrm{~N}_{4}$ photocatalyst could remove more than $68 \%$ continuous-flowing NO (initial concentration: $400 \mathrm{ppb}$ ) under visible-light irradiation in $30 \mathrm{~min}$. The findings of the trapping experiments confirmed that $\bullet \mathrm{O}_{2}{ }^{-}$and $\mathrm{h}^{+}$were the important active species in the NO oxidation reaction. Meanwhile, the transient photocurrent response and PL spectroscopy analyses proved that the unique $S$-scheme structure of the samples could enhance the charge separation efficiency. In situ DRIFTS revealed that the photocatalytic reaction pathway of NO removal over the $\mathrm{Sb}_{2} \mathrm{WO}_{6} / \mathrm{g}-\mathrm{C}_{3} \mathrm{~N}_{4}$ nanocomposite occurred via an oxygen-induced route. The present work proposes a new concept for fabricating efficient photocatalysts for photocatalytic ppb-level NO oxidation and provides deeper insights into the mechanism of photocatalytic NO oxidation.
\end{abstract}

(C) 2021, Dalian Institute of Chemical Physics, Chinese Academy of Sciences. Published by Elsevier B.V. All rights reserved.

\section{Introduction}

Most air pollution incidents involve the over-emission of $\mathrm{NO}_{x}$ from vehicles and plants $[1,2]$. Hence, it is urgently necessary to effectively decompose the $\mathrm{NO}_{x}$ in the atmosphere $[3,4]$. The photocatalytic technology, which can effectively convert $\mathrm{NO}_{x}$ to $\mathrm{NO}_{3}^{-}$, has been developed for a few years for $\mathrm{NO}_{x}$ removal [5-7]. However, most photocatalysts can only oxidize a high concentration of $\mathrm{NO}_{x}$ in the stable atmosphere, and only a few works have investigated the photocatalytic ppb-level $\mathrm{NO}_{x}$ oxidation in continuous-flowing air [8-10]. Hence, it is necessary to develop highly efficient photocatalysts for low-concentration $\mathrm{NO}_{x}$ removal.

The graphite-like carbon nitride $\left(\mathrm{g}-\mathrm{C}_{3} \mathrm{~N}_{4}\right)$, which is thermally stable, inexpensive, visible-light responsive, and has a large specific surface area [11-16], has attracted wide attention for photocatalytic low-concentration $\mathrm{NO}_{x}$ removal. Lin et al. [17] developed a novel ball-in-ball-structured g- $\mathrm{C}_{3} \mathrm{~N}_{4} @ \mathrm{SiO}_{2}$ photocatalyst with outstanding photocatalytic ability for hydrogen evolution and pollutant removal. Wang et al. [18] developed a porous g- $\mathrm{C}_{3} \mathrm{~N}_{4}$ catalyst that exhibits better photocatalytic ability than original g- $\mathrm{C}_{3} \mathrm{~N}_{4}$. However, g- $\mathrm{C}_{3} \mathrm{~N}_{4}$ can hardly be applied in the field of photocatalysis because of the high rate of recombination of photoexcited carriers. The fabrication of a composite

\footnotetext{
* Corresponding author. Tel: +86-27-87651816; Fax: +86-27-87887445; E-mail: gkzhang@whut.edu.cn ${ }^{\dagger}$ Contributed to this work equally.

This work was supported by the National Natural Science Foundation of China (51472194) and the Natural Science Foundation of Hubei Province (2016CFA078).

DOI: 10.1016/S1872-2067(20)63631-2 | http://www.sciencedirect.com/science/journal/18722067 | Chin. J. Catal., Vol. 42, No. 1, January 2021
} 
photocatalyst is an effective way to overcome the above-mentioned shortcoming [19-25]. For example, Wang et al. [26] fabricated a $\mathrm{Bi}_{3} \mathrm{TaO}_{7}$ QDs/g- $\mathrm{C}_{3} \mathrm{~N}_{4}$ photocatalyst that demonstrated enhanced photocatalytic ability than the single-phase photocatalyst for the photocatalytic degradation of antibiotics. Jiang et al. [27] developed $\mathrm{N}-\mathrm{TiO}_{2} / \mathrm{g}-\mathrm{C}_{3} \mathrm{~N}_{4}$, which demonstrated excellent photocatalytic performance for photocatalytic NO oxidation.

Nevertheless, despite the enhanced separation efficiency for the photoexcited charges, normal composite photocatalysts exhibit low oxidation and reduction properties than each of the components because of the electron migration pathway. Yu et al. [28-33] developed a S-scheme structured composite photocatalyst that exhibited an excellent charge separation property and enhanced photooxidation or photoreduction ability simultaneously. Ge et al. [34] fabricated a S-scheme $\mathrm{TiO}_{2} / \mathrm{CdS}$ nanofiber photocatalyst for hydrogen evaluation and studied the S-scheme charge transfer pathway in some detail. Jia et al. [35] synthesized a S-scheme heterojunction AgI/I-BiOAc by the one-pot milling method. The photocatalyst exhibited better performance than BiOAc and AgI for the degradation of organic pollutants. Thus, the coupling of unique S-scheme structured photocatalysts can evidently enhance the photocatalytic ability [36-40].

Over the years, $\mathrm{Sb}_{2} \mathrm{WO}_{6}$ has attracted considerable interest in the photocatalytic field because of its strong visible-light-harvesting capability [41-44]. Chen et al. [45] reported a Ag-loaded $\mathrm{Sb}_{2} \mathrm{WO}_{6}$ semiconductor that can effectively decompose organic pollutants such as rhodamine, methyl blue, and methyl orange. Ding et al. [44] synthesized 3D graphene aerogel $\mathrm{Sb}_{2} \mathrm{WO}_{6}$ hybrid by a facile hydrothermal process. Importantly, the band structure of such a photocatalyst matches that of $\mathrm{g}-\mathrm{C}_{3} \mathrm{~N}_{4}$, thus allowing the building of a S-scheme heterogeneous photocatalyst.

In this work, a series of S-scheme $\mathrm{Sb}_{2} \mathrm{WO}_{6} / \mathrm{g}-\mathrm{C}_{3} \mathrm{~N}_{4}$ nanocomposites were synthesized by an ultrasound-assisted method and were used for photocatalytic NO (400 ppb) oxidation under visible-light irradiation to assess their photocatalytic abilities. The $\mathrm{Sb}_{2} \mathrm{WO}_{6} / \mathrm{g}-\mathrm{C}_{3} \mathrm{~N}_{4}$ nanocomposite exhibited a higher NO removal efficiency than pure $\mathrm{Sb}_{2} \mathrm{WO}_{6}$ and g- $\mathrm{C}_{3} \mathrm{~N}_{4}$. Furthermore, the band structure, reaction pathway, and photocatalytic mechanism of the $\mathrm{Sb}_{2} \mathrm{WO}_{6} / \mathrm{g}_{-} \mathrm{C}_{3} \mathrm{~N}_{4}$ photocatalyst were analyzed by DRS, in situ DRIFTS, and trapping experiments, respectively. The photocatalytic mechanism investigation results confirmed that the enhanced photocatalytic activities are because of the $\mathrm{S}$-scheme structure of the $\mathrm{Sb}_{2} \mathrm{WO}_{6} / \mathrm{g}-\mathrm{C}_{3} \mathrm{~N}_{4}$ photocatalyst.

\section{Experimental}

\subsection{Photocatalyst preparation}

All the chemical reagents were of analytical-grade purity and used without further purification.

Synthesis of $\mathrm{Sb}_{2} \mathrm{WO}_{6}$. First, $1.37 \mathrm{~g}$ of $\mathrm{SbCl}_{3}$ and $0.76 \mathrm{~g}$ of $\left(\mathrm{NH}_{4}\right)_{10} \mathrm{~W}_{12} \mathrm{O}_{41} \cdot 5 \mathrm{H}_{2} \mathrm{O}$ were dissolved in $65 \mathrm{~mL}$ of deionized water with stirring for $30 \mathrm{~min}$. Then, the $\mathrm{pH}$ of above-mentioned mixed solution was adjusted to 2 with a 4
mol/L $\mathrm{NaOH}$ solution. The adjusted solution was added to a $100 \mathrm{~mL}$ PPL-lined stainless steel autoclave and heated at $180^{\circ} \mathrm{C}$ for $48 \mathrm{~h}$ in an oven [46]. The resulting precipitate was centrifuged, washed with water and ethanol several times, and dried at $60{ }^{\circ} \mathrm{C}$ overnight.

Synthesis of $\mathrm{g}-\mathrm{C}_{3} \mathrm{~N}_{4}$. The $\mathrm{g}-\mathrm{C}_{3} \mathrm{~N}_{4}$ powder was synthesized by heating melamine at $550{ }^{\circ} \mathrm{C}$ for $4 \mathrm{~h}$ at a $5{ }^{\circ} \mathrm{C} / \mathrm{min}$ heating rate $[47,48]$. The prepared light-yellow samples were ground, washed with water and ethanol several times, and dried at 60 ${ }^{\circ} \mathrm{C}$ overnight.

Preparation of $\mathrm{Sb}_{2} \mathrm{WO}_{6} / \mathrm{g}-\mathrm{C}_{3} \mathrm{~N}_{4}$ nanocomposite. Different amounts of $\mathrm{Sb}_{2} \mathrm{WO}_{6}$ particles $(5 \%, 10 \%, 15 \%$, and $20 \%$ to the weight of g- $\mathrm{C}_{3} \mathrm{~N}_{4}$, respectively) were dissolved in absolute ethanol under ultrasonication for $30 \mathrm{~min}$. Then, $0.5 \mathrm{~g}$ of the as-obtained g- $\mathrm{C}_{3} \mathrm{~N}_{4}$ sample was mixed with the $\mathrm{Sb}_{2} \mathrm{WO}_{6}$ solution under ultrasonication for $2 \mathrm{~h}$ and stirred for another $20 \mathrm{~h}$. The resulting nanocomposite was washed with deionized water and ethanol several times and dried at $60^{\circ} \mathrm{C}$ overnight.

\subsection{Characterization}

The lattice structures of the as-obtained samples were analyzed by X-ray diffraction (XRD) analysis using a Rigaku D/MAX-RB diffractometer with $\mathrm{Cu} K_{\alpha}$ radiation under the operation conditions of $40 \mathrm{kV}$ and $50 \mathrm{~mA}$. A Thermo Fisher VG Multilab 2000 spectrometer (UK) with a monochromatic Al $K_{\alpha}$ source was used to analyze the surface compositions and chemical states of the samples. Besides, the binding energies were revised based on the $\mathrm{C} 1 \mathrm{~s}$ peak of surface adventitious carbon at $284.5 \mathrm{eV}$. Scanning electron microscopy (SEM, JSM-5610LV, JEOL) and transmission electron microscopy (TEM, JEML 2100, JEOL) were performed to investigate the morphologies and microstructures of the samples. Fourier transform infrared (FT-IR, Nicolet, Thermo Fisher) spectroscopy and Raman spectroscopy were performed to identify the functional groups and molecular structures of the samples. The light absorption edges of the samples were recorded by UV-vis spectrophotometry (UV-2450, Shimadzu). The photoelectrochemical measurements were recorded using a CHI660C electrochemical analyzer. Photoluminescence (PL) emission spectra were recorded using a spectrofluorometer.

\subsection{Photocatalytic experiments}

The photocatalytic tests of the as-obtained samples were performed on a continuous-flow gas monitoring system (Fig. S1). Firstly, $50 \mathrm{mg}$ of photocatalyst was pasted onto a piece of glass, which was placed in the center of the sealed reactor $(35 \times 20 \times 12 \mathrm{~cm})$ with a quartz cover. Secondly, a Xe lamp was switched on after the reactant gas ( $400 \mathrm{ppb}$ NO, in air balance) was pumped into the reactor continuously to reach the adsorption-desorption equilibrium. Then, the concentrations of NO and $\mathrm{NO}_{2}$ in the reactor were continually recorded by a FT-IR spectrometer.

The removal ratio of $\mathrm{NO}$ was determined as:

$$
\eta(\%)=\left(1-C / C_{0}\right) \times 100 \%,
$$

where $C_{0}$ and $C$ denote the NO concentration in the inlet stream 

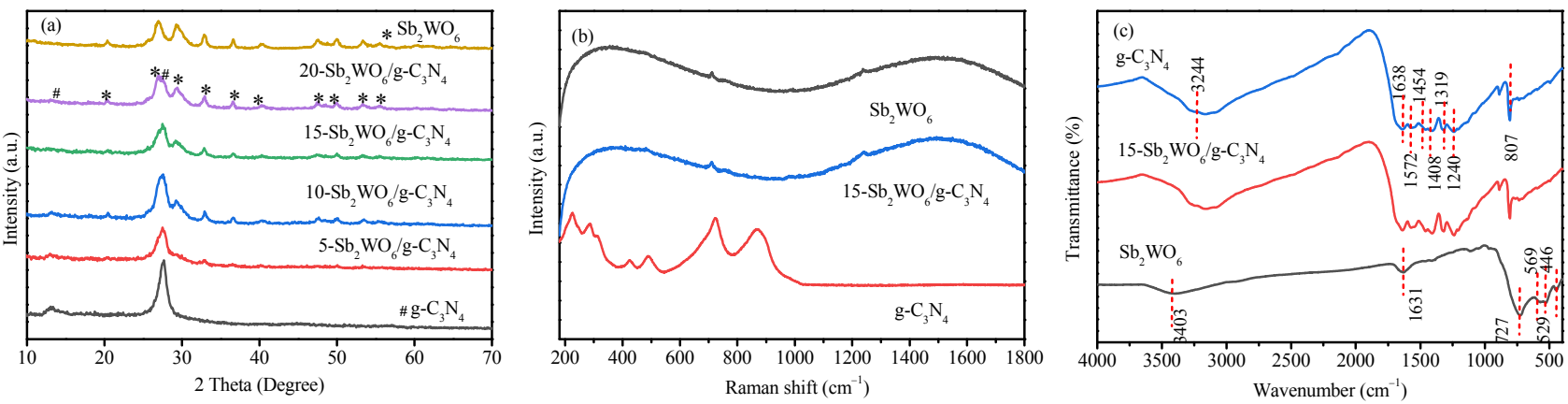

Fig. 1. XRD patterns (a), Raman spectra (b) and FT-IR spectra (c) of the $\mathrm{Sb}_{2} \mathrm{WO}_{6}, g-\mathrm{C}_{3} \mathrm{~N}_{4}$, and $15-\mathrm{Sb}_{2} \mathrm{WO}_{6} / g-\mathrm{C}_{3} \mathrm{~N}_{4}$ samples.

and outlet stream, respectively.

\section{Results and discussion}

\subsection{Characterization and analysis}

The XRD patterns of the series of $\mathrm{Sb}_{2} \mathrm{WO}_{6} / \mathrm{g}-\mathrm{C}_{3} \mathrm{~N}_{4}$ nanocomposites are displayed in Fig. 1(a). The diffraction peaks of pure $g-\mathrm{C}_{3} \mathrm{~N}_{4}$ at $27.51^{\circ}$ and $13.50^{\circ}$ are indexed to the (002) and (100) planes, respectively. The diffraction peaks of $\mathrm{Sb}_{2} \mathrm{WO}_{6}$ at $20.4^{\circ}, 26.90^{\circ}, 32.83^{\circ}, 36.37^{\circ}, 40.25^{\circ}, 47.49^{\circ}, 49.69^{\circ}$, and $53.07^{\circ}$ correspond to the (01-1), (1-11), (003), (20-1), (020), (202), (023), (2-2-1), and (3-10) planes, respectively. Furthermore, the characteristic diffraction peaks of $\mathrm{Sb}_{2} \mathrm{WO}_{6}$ and g- $\mathrm{C}_{3} \mathrm{~N}_{4}$ appeared in the XRD patterns of the $\mathrm{Sb}_{2} \mathrm{WO}_{6} / \mathrm{g}-\mathrm{C}_{3} \mathrm{~N}_{4}$ nanocomposite without any other impurities. More importantly, the changes in the peak intensities of the constituents are consistent with the change in the proportions of the constituents in the $\mathrm{Sb}_{2} \mathrm{WO}_{6} / \mathrm{g}-\mathrm{C}_{3} \mathrm{~N}_{4}$ photocatalyst.

The Raman spectra of the $\mathrm{Sb}_{2} \mathrm{WO}_{6}, \mathrm{~g}-\mathrm{C}_{3} \mathrm{~N}_{4}$, and $\mathrm{Sb}_{2} \mathrm{WO}_{6} / \mathrm{g}-\mathrm{C}_{3} \mathrm{~N}_{4}$ samples are presented in Fig. 1(b). The Raman spectrum of pure $\mathrm{Sb}_{2} \mathrm{WO}_{6}$ shows characteristic peaks at around $245,300,423,500,760$, and $880 \mathrm{~cm}^{-1}$, which are in agreement with that in reference [49]. The tiny peaks at 471,707 , and $1232 \mathrm{~cm}^{-1}$ are consistent with those reported for pure g- $\mathrm{C}_{3} \mathrm{~N}_{4}$ [50]. However, some characteristic peaks of $\mathrm{Sb}_{2} \mathrm{WO}_{6}$ cannot be observed clearly in the Raman spectrum of the 15- $\mathrm{Sb}_{2} \mathrm{WO}_{6} / \mathrm{g}-\mathrm{C}_{3} \mathrm{~N}_{4}$ nanocomposite because of the low content of $\mathrm{Sb}_{2} \mathrm{WO}_{6}$ in the nanocomposite. The functional groups and surface chemical bonds of the $\mathrm{Sb}_{2} \mathrm{WO}_{6}, \mathrm{~g}-\mathrm{C}_{3} \mathrm{~N}_{4}$, and $15-\mathrm{Sb}_{2} \mathrm{WO}_{6} / \mathrm{g}-\mathrm{C}_{3} \mathrm{~N}_{4}$ samples were investigated by FT-IR spectroscopy. As shown in Fig. 1(c), the FT-IR spectrum of pure $\mathrm{Sb}_{2} \mathrm{WO}_{6}$ has three obvious bands: the two broad bands at 1631 and $3403 \mathrm{~cm}^{-1}$ are ascribed to physically adsorbed $\mathrm{H}_{2} \mathrm{O}$, while the narrow bands at 500-727 $\mathrm{cm}^{-1}$ result from the stretching vibrations of $\mathrm{Sb}-\mathrm{O}, \mathrm{W}-\mathrm{O}$, and $\mathrm{W}-\mathrm{O}-\mathrm{W}$ bonds [49]. In the case of g- $\mathrm{C}_{3} \mathrm{~N}_{4}$, the absorption peak at $807 \mathrm{~cm}^{-1}$ is ascribed to the triazine ring modes [50]. The peaks at 1240,1319, 1408, 1454, and $1572 \mathrm{~cm}^{-1}$ are assigned to the aromatic C-N stretching, while the peak at $1638 \mathrm{~cm}^{-1}$ can be attributed to the $\mathrm{C}=\mathrm{N}$ stretching vibration modes [51]. Meanwhile, the peak at $3244 \mathrm{~cm}^{-1}$ corresponds to the $\mathrm{N}-\mathrm{H}$ stretching vibrations [52]. Besides, in agreement with the Raman analysis results, the main characteristic peaks of $\mathrm{Sb}_{2} \mathrm{WO}_{6}$ were not observed clearly in the FT-IR spectrum of the nanocomposite.

The morphology and microstructure of the photocatalysts were investigated by SEM, TEM, and HRTEM. Flower-like $\mathrm{Sb}_{2} \mathrm{WO}_{6}$ hierarchical microspheres are observed in Fig. S2(a). Moreover, the layered structure g- $\mathrm{C}_{3} \mathrm{~N}_{4}$ nanosheets can be seen in Fig. S2(b). Fig. S2(c) and (d) show that $\mathrm{Sb}_{2} \mathrm{WO}_{6}$ is composed of spherical particles that are bonded to the g- $\mathrm{C}_{3} \mathrm{~N}_{4}$ nanoflakes. Fig. 2(a) shows that the $\mathrm{Sb}_{2} \mathrm{WO}_{6}$ nanocrystals are adsorbed on the flake-like g- $\mathrm{C}_{3} \mathrm{~N}_{4}$. From Fig. 2(b), the interplanar distances of the lattice fringes were determined as 0.345 and $0.310 \mathrm{~nm}$ corresponding to the (1-11) and (022) crystal planes of $\mathrm{Sb}_{2} \mathrm{WO}_{6}$ particles, respectively. Additionally, the SAED pattern (Fig. 2(c)) confirms that the $\mathrm{Sb}_{2} \mathrm{WO}_{6}$ particles in the nanocomposite have a favorable crystallinity, and proves that $\mathrm{Sb}_{2} \mathrm{WO}_{6} / \mathrm{g}-\mathrm{C}_{3} \mathrm{~N}_{4}$ nanocomposites were successful prepared. HAADF-STEM analysis was performed to examine the microstructure and composition of $\mathrm{Sb}_{2} \mathrm{WO}_{6} / \mathrm{g}-\mathrm{C}_{3} \mathrm{~N}_{4}$. Fig. 2(d)-(k) reveal the uniform distribution of $\mathrm{C}, \mathrm{N}, \mathrm{O}, \mathrm{Sb}$, and $\mathrm{W}$ elements in
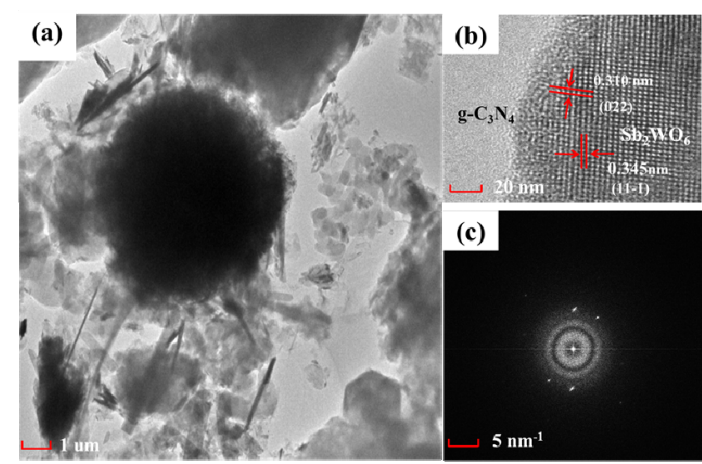

(c)
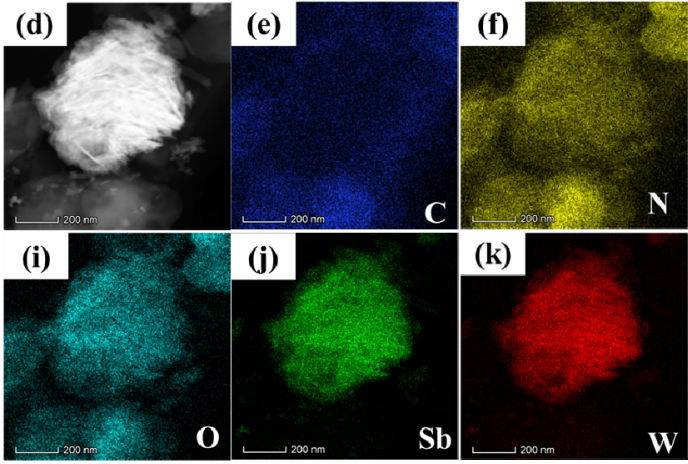

(k)

Fig. 2. TEM (a), HRTEM (b), and HAADF-STEM (c) images and the corresponding EDS elemental mapping images $(\mathrm{d}-\mathrm{k})$ of the $15-\mathrm{Sb}_{2} \mathrm{WO}_{6} / \mathrm{g}-\mathrm{C}_{3} \mathrm{~N}_{4}$ nanocomposite. 
the $15-\mathrm{Sb}_{2} \mathrm{WO}_{6} / \mathrm{g}-\mathrm{C}_{3} \mathrm{~N}_{4}$ sample. These results strongly suggest the successful construction of a $\mathrm{Sb}_{2} \mathrm{WO}_{6} / \mathrm{g}-\mathrm{C}_{3} \mathrm{~N}_{4}$ heterojunction.

XPS analysis was performed to confirm the surface compositions and chemical states of the pure $\mathrm{Sb}_{2} \mathrm{WO}_{6}$, pure g- $\mathrm{C}_{3} \mathrm{~N}_{4}$, and $15-\mathrm{Sb}_{2} \mathrm{WO}_{6} / \mathrm{g}-\mathrm{C}_{3} \mathrm{~N}_{4}$ samples. Fig. 3(a) shows the XPS survey spectrum of each sample. The $\mathrm{C} 1 \mathrm{~s}$ spectra of the samples show similar peaks at 284.8 and $288.2 \mathrm{eV}$ (Fig. 3(b)), which correspond to adsorbed carbon and the $\mathrm{C}_{-} \mathrm{N}_{3}$ group, respectively $[53,54]$. The $\mathrm{N} 1 \mathrm{~s}$ spectra of the samples are fitted to four peaks at 404.6, 400.4, and $398.7 \mathrm{eV}$ (Fig. 3(c)). The peak at the highest binding energy of $398.7 \mathrm{eV}$ is ascribed to the $s p^{2}$-bonded nitrogen $(\mathrm{C}-\mathrm{N}-\mathrm{C})$, the one at $399.9 \mathrm{eV}$ corresponds to the tertiary nitrogen bonded to carbon (N-(C)3), the one at $401.1 \mathrm{eV}$ corresponds to the amino groups $(\mathrm{C}-\mathrm{N}-\mathrm{H})$, the peak at the lowest binding energy of $404.5 \mathrm{eV}$ resulted from positive charge localization in the heterocycles [55,56]. As shown in Fig. 3(d), the peaks at 530.1 and $530.3 \mathrm{eV}$ in the $01 \mathrm{~s}$ spectra of the $\mathrm{Sb}_{2} \mathrm{WO}_{6}$ and $15-\mathrm{Sb}_{2} \mathrm{WO}_{6} / \mathrm{g}-\mathrm{C}_{3} \mathrm{~N}_{4}$ samples are ascribed to $\mathrm{W}-\mathrm{O}$. In addition, compared with the $01 \mathrm{~s}$ spectrum of $\mathrm{Sb}_{2} \mathrm{WO}_{6}$, a new peak appeared in the $01 \mathrm{~s}$ spectrum of the $\mathrm{Sb}_{2} \mathrm{WO}_{6} / \mathrm{g}-\mathrm{C}_{3} \mathrm{~N}_{4}$ nanocomposite at $531.9 \mathrm{eV}$, which is attributed to the oxygen-containing intermediates derived from the incomplete thermal condensation of melamine [57]. The Sb $3 d$ spectrum of the nanocomposite deconvoluted into two peaks at 529.8 and $539.3 \mathrm{eV}$ (Fig. 3(e)), which are attributed to $\mathrm{Sb} 3 d_{5 / 2}$ and $\mathrm{Sb}$ $3 d_{3 / 2}$ of $\mathrm{Sb}^{3+}$, respectively [58]. As shown in Fig. 3(f), the peaks at $35.1 \mathrm{eV}$ and $37.1 \mathrm{eV}$ in the $\mathrm{W} 4 f$ spectra of the nanocomposites resulted from $\mathrm{W}^{6+}$, while the peaks at 33.6 and $35.3 \mathrm{eV}$ resulted from $\mathrm{W}^{5+}[59,60]$. As shown in Fig. 3, compared with the pure constituents, the binding energies of $\mathrm{C} 1 s, 01 s, \mathrm{Sb} 3 d$, and $\mathrm{W} 4 f$ slight shifted for the $15-\mathrm{Sb}_{2} \mathrm{WO}_{6} / \mathrm{g}-\mathrm{C}_{3} \mathrm{~N}_{4}$ nanocomposite because of the electron screening effect resulting from the change in electron density [61]. The above phenomena imply the presence of a strong interface effect between $\mathrm{Sb}_{2} \mathrm{WO}_{6}$ and g- $\mathrm{C}_{3} \mathrm{~N}_{4}$ in the nanocomposite [62].

The light absorption range of a photocatalyst is the key factor for evaluating its photocatalytic activity. As can be seen in Fig. 4(a), compared with the absorption edges of $\mathrm{g}-\mathrm{C}_{3} \mathrm{~N}_{4}$, the absorption edges of the $\mathrm{Sb}_{2} \mathrm{WO}_{6} / \mathrm{g}-\mathrm{C}_{3} \mathrm{~N}_{4}$ nanocomposite are slightly red shifted, and the shift gradually increased with an increase in the amount of $\mathrm{Sb}_{2} \mathrm{WO}_{6}$ from $5 \%$ to $15 \%$ in the nanocomposite (Fig. 4(b)). Besides, the band gaps of the samples can be calculated using the following formula:

$$
a h v=\mathrm{A}\left(\mathrm{h} v-E_{\mathrm{g}}\right)^{n / 2} \text {, }
$$

where $\alpha, v, h, A$, and $E_{\mathrm{g}}$ represent the coefficients of absorption, light frequency, Planck constant, constant number, and band gap, respectively. For $\mathrm{Sb}_{2} \mathrm{WO}_{6}$ and g- $\mathrm{C}_{3} \mathrm{~N}_{4}, n$ is 4 . Thus, as shown in Fig. 4(c), the $E_{\mathrm{g}}$ values of $\mathrm{Sb}_{2} \mathrm{WO}_{6}$ and g- $\mathrm{C}_{3} \mathrm{~N}_{4}$ were estimated as 2.25 and $2.65 \mathrm{eV}$, respectively. The Mott-Schottky plots of the $\mathrm{Sb}_{2} \mathrm{WO}_{6}, \mathrm{~g}-\mathrm{C}_{3} \mathrm{~N}_{4}$, and $15-\mathrm{Sb}_{2} \mathrm{WO}_{6} / \mathrm{g}-\mathrm{C}_{3} \mathrm{~N}_{4}$ samples were evaluated to study the effect on charge carrier concentration. As shown in Fig. $4(\mathrm{~d})$, the flat potentials $\left(E_{\mathrm{FB}}\right)$ are $-0.45,-1.14$, and $-0.60 \mathrm{~V}$ vs. $\mathrm{Ag} / \mathrm{AgCl}(\mathrm{pH}=6.8)$ for $\mathrm{Sb}_{2} \mathrm{WO}_{6}, \mathrm{~g}-\mathrm{C}_{3} \mathrm{~N}_{4}$, and $15-\mathrm{Sb}_{2} \mathrm{WO}_{6} / \mathrm{g}-\mathrm{C}_{3} \mathrm{~N}_{4}$, respectively. The $E_{\mathrm{FB}}$, which was measured using a $\mathrm{Ag} / \mathrm{AgCl}$ reference electrode, could be converted into the normal hydrogen electrode (NHE) potentials using the following equation [63]:

$$
E_{\mathrm{FB}}=E_{\mathrm{Ag} / \mathrm{AgCl}}+0.059 \times \mathrm{pH}+E^{0} \mathrm{Ag} / \mathrm{AgCl} \text {, }
$$

where the $\mathrm{pH}$ of the electrolyte is 6.8 and $E^{0} \mathrm{Ag} / \mathrm{AgCl}$ is $0.197 \mathrm{eV}$. Hence, the $E_{\mathrm{FB}}$ values of $\mathrm{Sb}_{2} \mathrm{WO}_{6}$ and $\mathrm{g}-\mathrm{C}_{3} \mathrm{~N}_{4}$ are calculated as 0.15 and $-0.54 \mathrm{~V}$ vs. NHE, respectively. In addition, the $E_{\mathrm{CB}}$ is very close to ( $-0.3 \mathrm{~V}$ more negative) the $E_{\mathrm{FB}}$ for an n-type semiconductor. Therefore, the $E_{\mathrm{CB}}$ values of $\mathrm{Sb}_{2} \mathrm{WO}_{6}$ and g- $\mathrm{C}_{3} \mathrm{~N}_{4}$ are equivalent to -0.15 and $-0.84 \mathrm{~V}$ vs. NHE, respectively. Combined with the UV-vis DRS findings, the corresponding $E_{\mathrm{VB}}$ values of $\mathrm{Sb}_{2} \mathrm{WO}_{6}$ and $\mathrm{g}-\mathrm{C}_{3} \mathrm{~N}_{4}$ were calculated as 2.10 and $1.81 \mathrm{eV}$
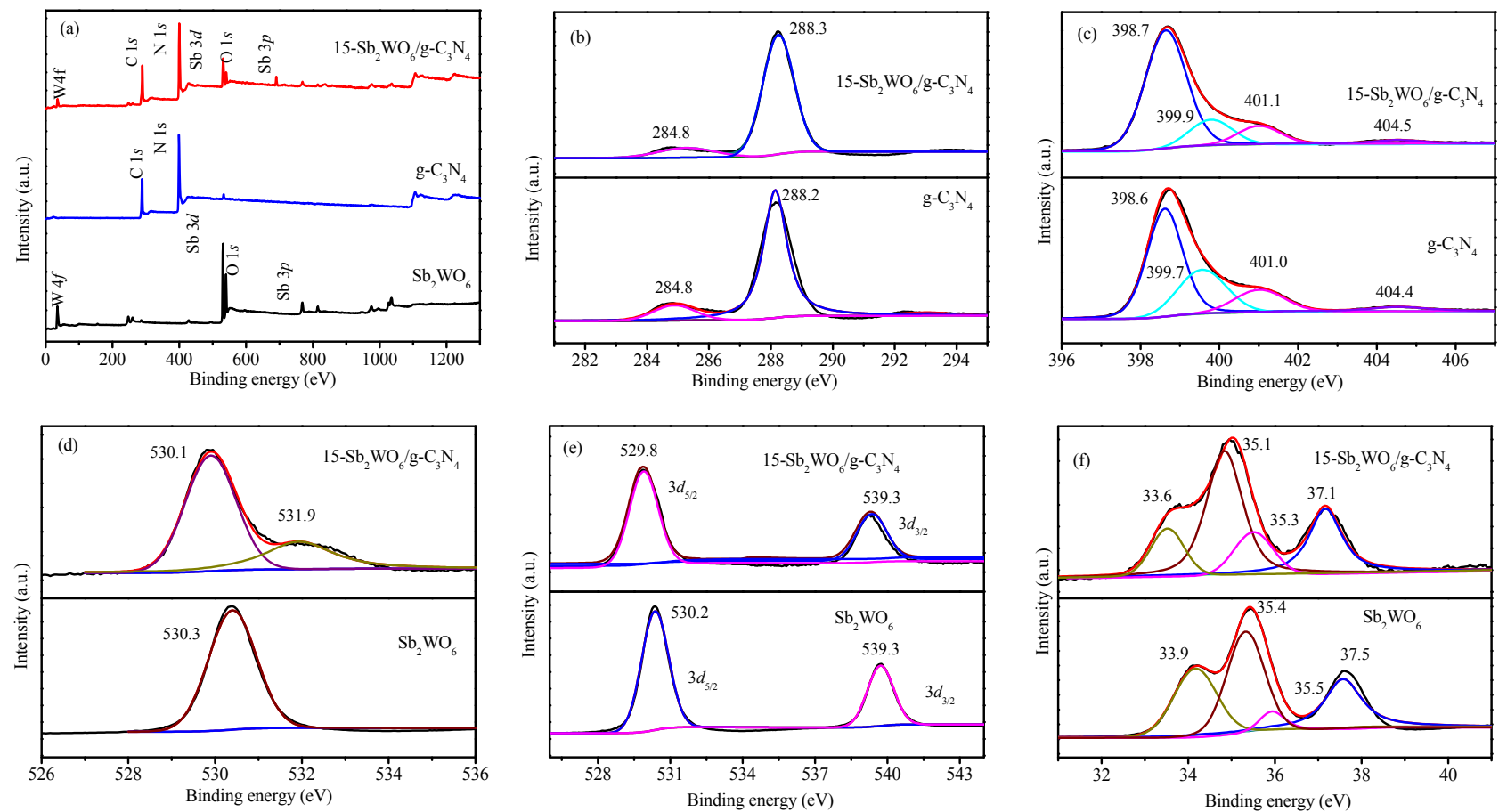

Fig. 3. XPS spectra of $\mathrm{Sb}_{2} \mathrm{WO}_{6}, \mathrm{gC}_{3} \mathrm{~N}_{4}$, and $15-\mathrm{Sb}_{2} \mathrm{WO}_{6} / \mathrm{g}-\mathrm{C}_{3} \mathrm{~N}_{4}$. (a) Survey spectra; (b) C $1 s$; (c) N 1s; (d) $01 s$; (e) Sb $3 d$; (f) W $4 f$ spectra. 

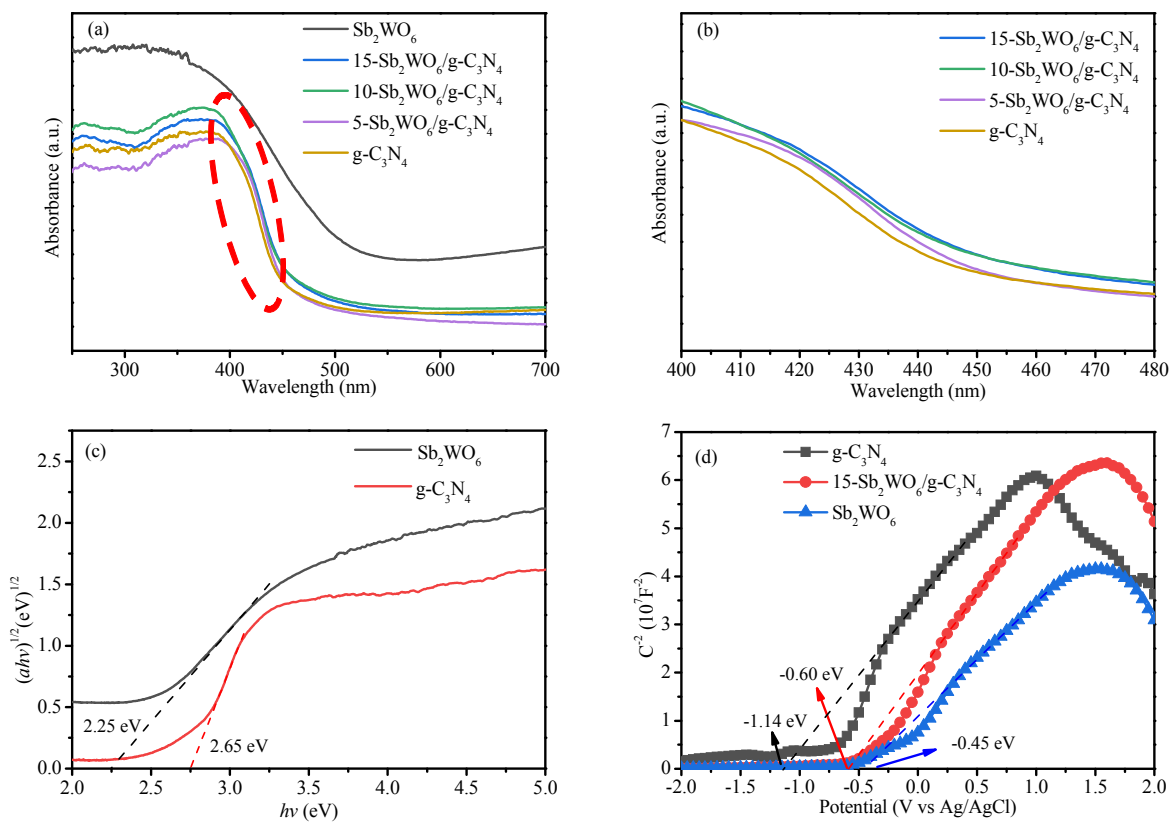

Fig. 4. UV-vis diffuse reflection spectra of the as-prepared samples (a) and enlarged image (b) of the zone marked in (a); (Ahv) ${ }^{1 / 2}$ versus $h v$ plots (c) and Mott-Schottky plots (d) of pure $\mathrm{Sb}_{2} \mathrm{WO}_{6}$ and g- $\mathrm{C}_{3} \mathrm{~N}_{4}$.

vs. NHE, respectively.

\subsection{Photocatalytic performance}

The photocatalytic abilities of all the photocatalysts were assessed by the visible-light-driven photocatalytic continuous-flow low-concentration NO removal experiments. Fig. 5(a) displays the NO removal ratio of the $\mathrm{Sb}_{2} \mathrm{WO}_{6}, \mathrm{~g}-\mathrm{C}_{3} \mathrm{~N}_{4}$, and $\mathrm{Sb}_{2} \mathrm{WO}_{6} / \mathrm{g}-\mathrm{C}_{3} \mathrm{~N}_{4}$ samples. The pure $\mathrm{Sb}_{2} \mathrm{WO}_{6}$ sample could hardly remove NO under visible-light irradiation, while pure $\mathrm{g}-\mathrm{C}_{3} \mathrm{~N}_{4}$ could degrade approximately 55\% NO after 30 min under the same conditions. Compared with the as-obtained $\mathrm{Sb}_{2} \mathrm{WO}_{6}$ and g- $\mathrm{C}_{3} \mathrm{~N}_{4}$ samples, the $\mathrm{Sb}_{2} \mathrm{WO}_{6} / \mathrm{g}_{-} \mathrm{C}_{3} \mathrm{~N}_{4}$ nanocomposite exhibited higher activities for photocatalytic NO oxidation. More importantly, among the as-synthesized samples, the $15-\mathrm{Sb}_{2} \mathrm{WO}_{6} / \mathrm{g}-\mathrm{C}_{3} \mathrm{~N}_{4}$ sample exhibited the best visible-light-driven photocatalytic activity with the removal of $68 \%$ NO after 30 min. Fig. 5(b) displays the reusability and stability of the $15-\mathrm{Sb}_{2} \mathrm{WO}_{6} / \mathrm{g}-\mathrm{C}_{3} \mathrm{~N}_{4}$ nanocomposite. The ratio of photocatalytic NO removal of the $15-\mathrm{Sb}_{2} \mathrm{WO}_{6} / \mathrm{g}-\mathrm{C}_{3} \mathrm{~N}_{4}$ photocatalyst decreased by only $5 \%$ after five cycles. Moreover, as shown in Fig. 5(c) and 5(d), the XRD and FT-IR spectra of the
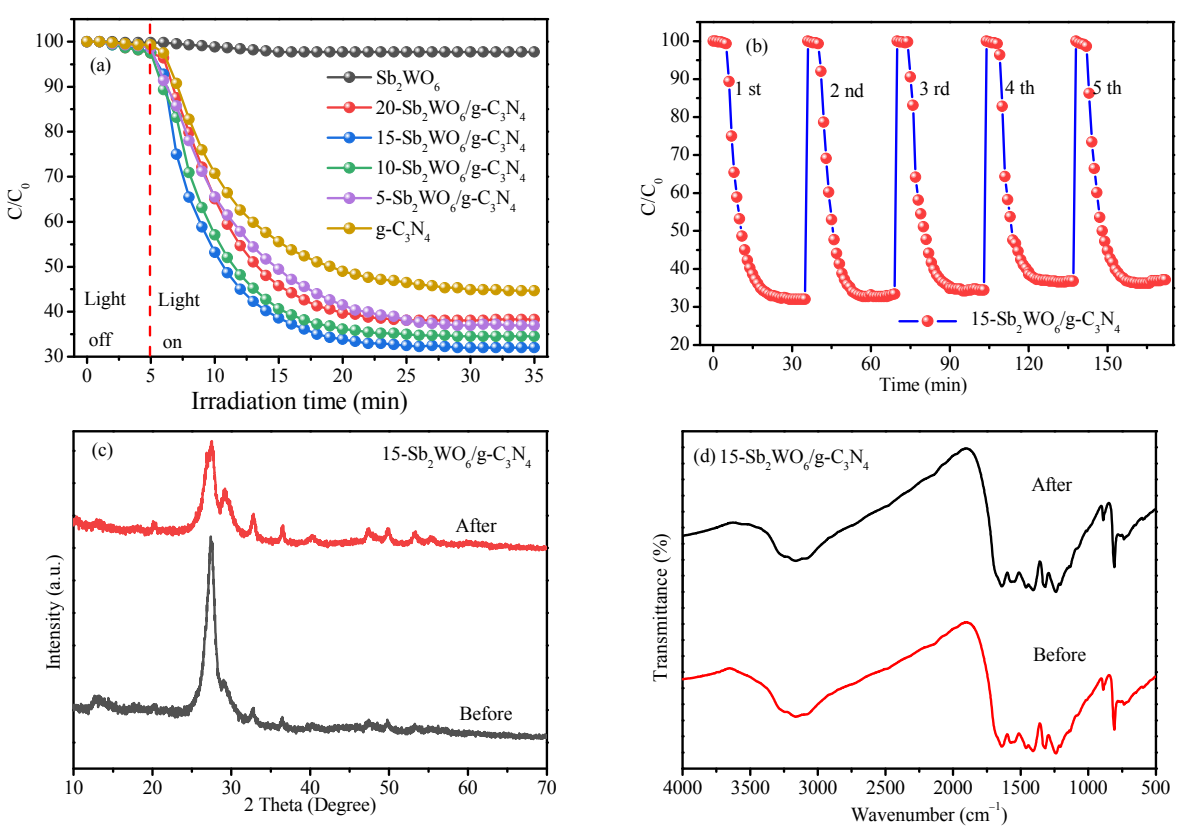

Fig. 5. (a) Photocatalytic NO oxidation of the as-prepared samples; (b) Five consecutive runs of NO removal over the $15-\mathrm{Sb}_{2} \mathrm{WO}_{6} / \mathrm{g} \mathrm{C}_{3} \mathrm{~N}_{4}$ nanocomposite; XRD patterns (c) and FT-IR spectra (d) of 15-Sb $2 \mathrm{WO}_{6} / \mathrm{g}-\mathrm{C}_{3} \mathrm{~N}_{4}$ nanocomposite before and after photocatalytic reaction. 

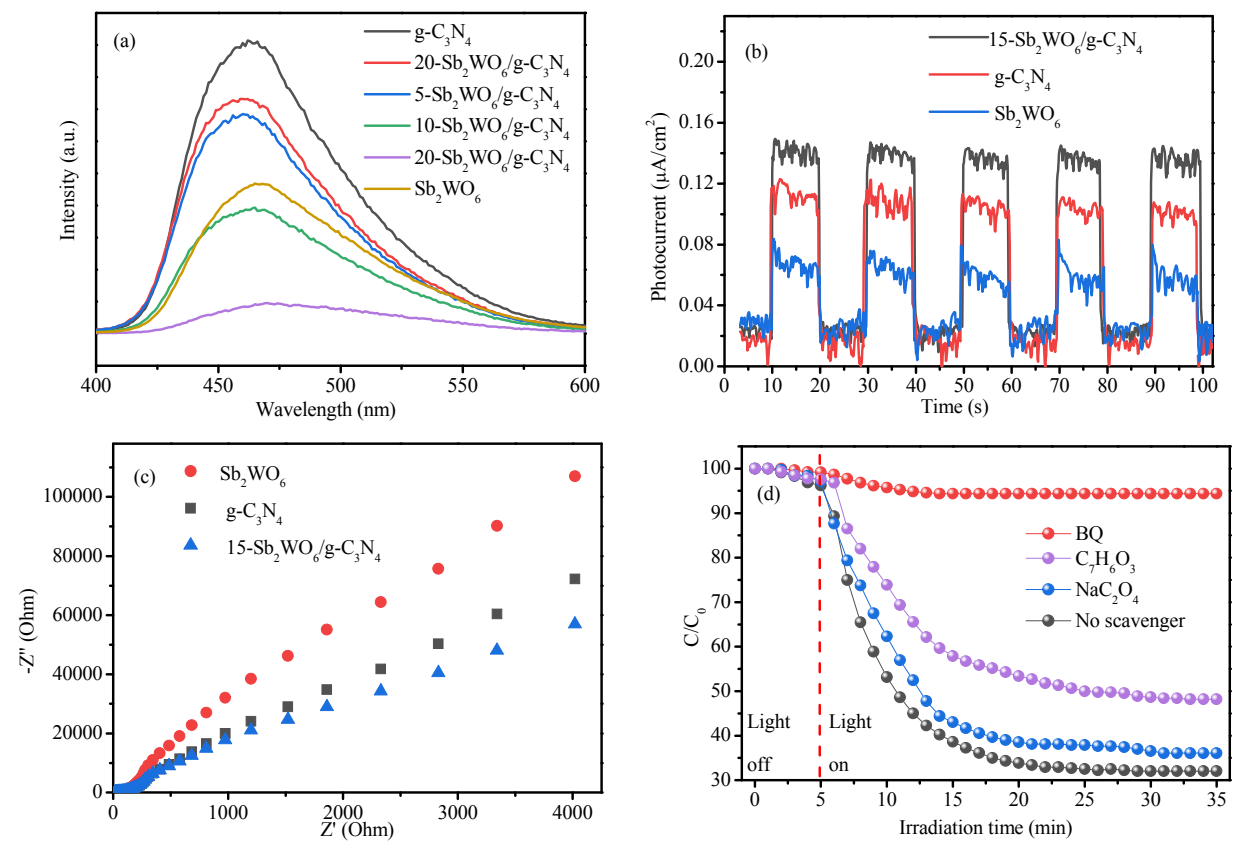

Fig. 6. (a) PL spectra of g- $\mathrm{C}_{3} \mathrm{~N}_{4}$ and $\mathrm{Sb}_{2} \mathrm{WO}_{6} / \mathrm{g}-\mathrm{C}_{3} \mathrm{~N}_{4}$ nanocomposites; Photocurrent responses (b) and EIS spectra (c) of $\mathrm{Sb}_{2} \mathrm{WO}_{6}$, g- $\mathrm{C}_{3} \mathrm{~N}_{4}$, and $15-\mathrm{Sb}_{2} \mathrm{WO}_{6} / \mathrm{g}-\mathrm{C}_{3} \mathrm{~N}_{4}$ samples; (d) Results of radical species trapping experiments of the $15-\mathrm{Sb}_{2} \mathrm{WO}_{6} / \mathrm{g}-\mathrm{C}_{3} \mathrm{~N}_{4}$ sample and the removal of NO with different scavengers.

fresh and used $15-\mathrm{Sb}_{2} \mathrm{WO}_{6} / \mathrm{g}-\mathrm{C}_{3} \mathrm{~N}_{4}$ samples do not show obvious changes, which indicates that the $15-\mathrm{Sb}_{2} \mathrm{WO}_{6} / \mathrm{g}-\mathrm{C}_{3} \mathrm{~N}_{4}$ sample was stable during the removal of NO.

\subsection{Photocatalytic mechanism}

As shown in the Fig. 6(a), the recombination rate of the photoexcited carriers in the photocatalysts was tested by PL spectroscopy performed with an excitation wavelength of 365 $\mathrm{nm}$. Compared with the emission intensity of g- $\mathrm{C}_{3} \mathrm{~N}_{4}$, the emission intensity of the $\mathrm{Sb}_{2} \mathrm{WO}_{6} / \mathrm{g}-\mathrm{C}_{3} \mathrm{~N}_{4}$ photocatalysts decreased significantly. Particularly, the $15-\mathrm{Sb}_{2} \mathrm{WO}_{6} / \mathrm{g}-\mathrm{C}_{3} \mathrm{~N}_{4}$ sample shows the weakest intensity, which indicates the effective separation of photogenerated charge carriers by the heterojunction structure of the nanocomposite.

Further, the separation efficiency for the photoinduced carriers of the photocatalysts was assessed by photocurrent analysis performed under visible-light irradiation. Among the as-obtained photocatalysts, the $15-\mathrm{Sb}_{2} \mathrm{WO}_{6} / \mathrm{g}-\mathrm{C}_{3} \mathrm{~N}_{4}$ nanocomposite showed the highest photogenerated current (Fig. 6(b)), which suggests that $15-\mathrm{Sb}_{2} \mathrm{WO}_{6} / \mathrm{g}-\mathrm{C}_{3} \mathrm{~N}_{4}$ can more effectively separate the photogenerated carriers during the photocatalytic reaction. Moreover, EIS was performed to assess the charge-transfer efficiency of the semiconductor. The $15-\mathrm{Sb}_{2} \mathrm{WO}_{6} / \mathrm{g}-\mathrm{C}_{3} \mathrm{~N}_{4}$ nanocomposite exhibited the smallest arc radius of the Nyquist circle compared with pure $\mathrm{Sb}_{2} \mathrm{WO}_{6}$ and g- $\mathrm{C}_{3} \mathrm{~N}_{4}$ (Fig. 6(c)), which indicates that the $15-\mathrm{Sb}_{2} \mathrm{WO}_{6} / \mathrm{g}-\mathrm{C}_{3} \mathrm{~N}_{4}$ nanocomposite can more effectively transport the charges.

Moreover, the photocatalytic mechanism of the $15-\mathrm{Sb}_{2} \mathrm{WO}_{6} / \mathrm{g}-\mathrm{C}_{3} \mathrm{~N}_{4}$ nanocomposite for the removal of $\mathrm{NO}$ was investigated by radical species trapping experiments. Benzoquinone (BQ), salicylic acid $\left(\mathrm{C}_{7} \mathrm{H}_{6} \mathrm{O}_{3}\right)$, and sodium oxalate $\left(\mathrm{Na}_{2} \mathrm{C}_{2} \mathrm{O}_{4}\right)$ were used as the scavengers of $\bullet \mathrm{O}_{2^{-}}, \bullet \mathrm{OH}$, and $\mathrm{h}^{+}$, respectively. Fig. 6(d) shows the removal ratio of NO over the $15-\mathrm{Sb}_{2} \mathrm{WO}_{6} / \mathrm{g}-\mathrm{C}_{3} \mathrm{~N}_{4}$ sample in the presence of different scavengers. Compared with the blank group, the addition of $\mathrm{BQ}$ significantly affected the performance of photocatalytic NO removal, which indicates that $\bullet \mathrm{O}_{2}$ - plays the main role in the $\mathrm{NO}$ removal reaction. Besides, the addition of $\mathrm{C}_{7} \mathrm{H}_{6} \mathrm{O}_{3}$ slightly affected the photocatalytic activity, which implies that $\bullet \mathrm{OH}$ partly participates in the photocatalytic reaction. Meanwhile, the decrease in $\mathrm{NO}$ in the case of $\mathrm{Na}_{2} \mathrm{C}_{2} \mathrm{O}_{4}$ is similar to that in the case of blank group, which suggests that $\mathrm{h}^{+}$was not efficiently involved in the photocatalytic NO removal reaction. The oxygen and vapor contents in the photocatalytic reaction can explain the above findings. We designed an oxygen-enriched and water-deficient environment in the photocatalytic experiment. Hence, the photoinduced electrons preferably reacted with oxygen, while the photoinduced holes could not obtain enough vapor to form $\bullet \mathrm{OH}$.

The reaction pathways of NO removal were studied by in situ DRIFTS (Fig. 7). After irradiation under visible light for 5 min, some new absorption bands and significant changes appeared in the regions of 850-1000, 1050-1200, and 2800-3600 $\mathrm{cm}^{-1}$, which are attributed to some reaction intermediates $\mathrm{NO}_{2}, \mathrm{~N}_{2} \mathrm{O}_{3}, \mathrm{NO}^{-}$, and $\left.\mathrm{NO}_{2}\right)$ and the final products $\left(\mathrm{NO}_{2}{ }^{-}\right.$and $\left.\mathrm{NO}_{3}{ }^{-}\right)$[64]. As displayed in Table $\mathrm{S} 1$, the absorption bands at $858,880,891,928,948$, and $1128 \mathrm{~cm}^{-1}$ can be attributed to $\mathrm{NO}_{2}-[65]$. The peaks at 961 and $976 \mathrm{~cm}^{-1}$ belong to the oxidized $\mathrm{N}_{2} \mathrm{O}_{3}$ [66]. The bands at 1063, 1080, 1100, and $1285 \mathrm{~cm}^{-1}$ can be indexed to nitrates $\left(\mathrm{NO}_{3}{ }^{-}\right)[17,67]$, and the bands at 1090 and $1124 \mathrm{~cm}^{-1}$ can be assigned to $\mathrm{N}_{2} \mathrm{O}$. The peaks at 1170 and $1178 \mathrm{~cm}^{-1}$ belong to oxidized NO-. Moreover, a peak corresponding to $\mathrm{N}_{2} \mathrm{O}^{-}$appeared at $1144 \mathrm{~cm}^{-1}$ [68]. The bands at 2823, 2855, 2950, 3460, 3601, and $3795 \mathrm{~cm}^{-1}$ can be assigned to $\mathrm{NO}_{2}$ [69]. The bands at 1320-1390 and 


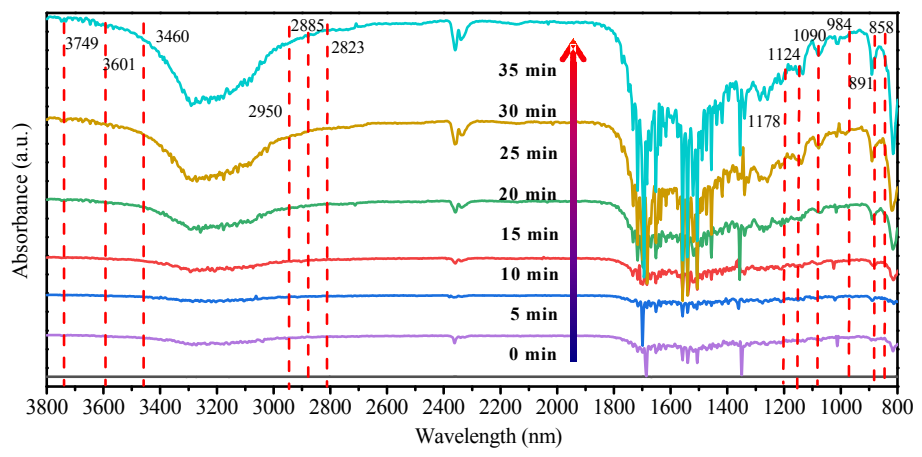

Fig. 7. In situ DRIFT spectra of the photocatalytic reaction of $\mathrm{NO}$ over $15-\mathrm{Sb}_{2} \mathrm{WO}_{6} / \mathrm{g}-\mathrm{C}_{3} \mathrm{~N}_{4}$ nanocomposite under visible-light irradiation.

$1510-1615 \mathrm{~cm}^{-1}$ can be assigned to the double bond stretching vibrations of $-\mathrm{NO}_{2}$ [70]. Besides, g- $\mathrm{C}_{3} \mathrm{~N}_{4}$ slightly decomposes under strong light irradiation, and the band at $1620-1680 \mathrm{~cm}^{-1}$ can be attributed to $-\mathrm{C}=\mathrm{C}-$ from $\mathrm{g}-\mathrm{C}_{3} \mathrm{~N}_{4}$.

Combined with the above findings of the trapping experiments, the main radical species in the photocatalytic NO removal reaction was found to be $\bullet \mathrm{O}_{2}$, while the secondary species was found to be $\bullet \mathrm{OH}$. Nitrite and nitrate are the final oxidation products of photocatalytic NO removal. Hence, the photocatalytic process of $\mathrm{NO}$ removal over the $\mathrm{Sb}_{2} \mathrm{WO}_{6} / \mathrm{g}-\mathrm{C}_{3} \mathrm{~N}_{4}$ nanocomposite is identified to occur via an oxygen-induced route. The detailed $\mathrm{NO}$ removal reactions are as follows $\left(\mathrm{NO}_{x}=\right.$ $\mathrm{NO}_{2}-\mathrm{N}_{2} \mathrm{O}_{3}, \mathrm{NO}^{-}$, and $\mathrm{N}_{2} \mathrm{O}$ ):

$$
\begin{aligned}
& \cdot \mathrm{O}_{2}+\mathrm{e}^{-} \rightarrow \bullet \mathrm{O}_{2^{-}} \\
& \bullet \mathrm{OH}^{-+} \mathrm{h}^{+-}=\bullet \cdot \mathrm{OH} \\
& \mathrm{NO}_{x}+\bullet \mathrm{O}_{2}^{-} \rightarrow \mathrm{NO}_{2}-/ \mathrm{NO}_{3}^{-} \\
& \mathrm{NO}_{x}+2 \cdot \mathrm{OH}^{-} \rightarrow \mathrm{NO}_{2}+\mathrm{H}_{2} \mathrm{O} \\
& \mathrm{NO}_{2}+2 \cdot \mathrm{OH}^{-} \rightarrow \mathrm{NO}_{2}{ }^{-} / \mathrm{NO}_{3}{ }^{-}+\mathrm{H}^{+} \\
& \mathrm{NO}_{2}{ }^{-}+\bullet \mathrm{OH} / \bullet \mathrm{O}_{2}-\rightarrow \mathrm{NO}_{3}{ }^{-}
\end{aligned}
$$

Based on the above analyses and references, the entire process of electron migration and photocatalytic mechanism for NO removal over the $\mathrm{Sb}_{2} \mathrm{WO}_{6} / g-\mathrm{C}_{3} \mathrm{~N}_{4}$ nanocomposite can be divided to three parts (Fig. 8). As shown in Fig. 8, the first step is before the contact of the components. In this step, $\mathrm{Sb}_{2} \mathrm{WO}_{6}$ and $\mathrm{g}_{-} \mathrm{C}_{3} \mathrm{~N}_{4}$ are in their original states, and the $E_{\mathrm{FB}}$ of $\mathrm{Sb}_{2} \mathrm{WO}_{6}$ is lower than that of g- $\mathrm{C}_{3} \mathrm{~N}_{4}$. The second step is after the contact of the components in the dark. The electrons can migrate from g- $\mathrm{C}_{3} \mathrm{~N}_{4}$ to $\mathrm{Sb}_{2} \mathrm{WO}_{6}$ to build a new Fermi level $\left(\mathrm{F}_{\mathrm{B}}{ }^{*}\right.$ in the Fig. 8). Simultaneously, a built-in electric field (IEF) is generated be-

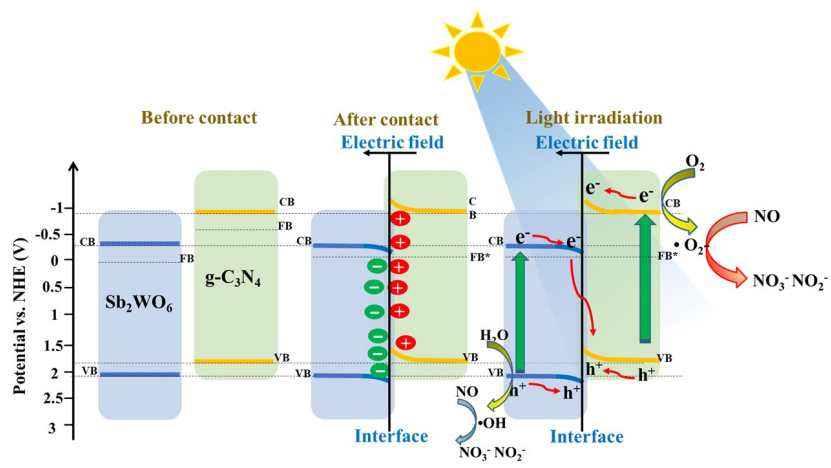

Fig. 8. S-scheme photocatalytic mechanism for $\mathrm{Sb}_{2} \mathrm{WO}_{6} / \mathrm{g}-\mathrm{C}_{3} \mathrm{~N}_{4}$ nanocomposite under visible-light irradiation. tween the components in the direction from the higher original Fermi level to a lower level. The last step is the photocatalytic reaction. The photogenerated electrons in the $\mathrm{CB}$ of $\mathrm{Sb}_{2} \mathrm{WO}_{6}$ combine with the photoinduced holes in the VB of g- $\mathrm{C}_{3} \mathrm{~N}_{4}$ under the built-in electric field. Meanwhile, $\bullet \mathrm{O}_{2}$ - radicals are formed by the photoexcited electrons and $\mathrm{O}_{2}$ in the $\mathrm{CB}$ of $\mathrm{g}-\mathrm{C}_{3} \mathrm{~N}_{4}$, and - $\mathrm{OH}$ radicals are generated via the reaction of the photogenerated holes and water in the $\mathrm{VB}$ of $\mathrm{Sb}_{2} \mathrm{WO}_{6}$. Lastly, the absorbed NO is oxidized by the formed radicals.

\section{Conclusions}

$\mathrm{Sb}_{2} \mathrm{WO}_{6} / \mathrm{g}-\mathrm{C}_{3} \mathrm{~N}_{4}$ nanocomposites were successfully fabricated by an ultrasound-assisted method. Among the as-synthesized samples, the $15-\mathrm{Sb}_{2} \mathrm{WO}_{6} / \mathrm{g}-\mathrm{C}_{3} \mathrm{~N}_{4}$ nanocomposite demonstrated the best photocatalytic performance for the complete conversion of ppb-level NO to nitrate under visible-light irradiation. Meanwhile, PL spectroscopy, transient photocurrent response analysis, and EIS confirmed that the $15-\mathrm{Sb}_{2} \mathrm{WO}_{6} / \mathrm{g}-\mathrm{C}_{3} \mathrm{~N}_{4}$ nanocomposite could effectively separate the photoexcited charges in the visible-light-driven photocatalytic reaction. Hence, the outstanding photocatalytic performance of the nanocomposite resulted from its excellent separation efficiency for the photogenerated carriers. The PL spectra, photocurrent response, and EIS spectra of the as-obtained samples indicated that the S-scheme structure of the $\mathrm{Sb}_{2} \mathrm{WO}_{6} / \mathrm{g}-\mathrm{C}_{3} \mathrm{~N}_{4}$ photocatalyst effectively enhanced the separation efficiency for the photogenerated carriers. More importantly, the results of in situ DRIFTS indicated that the main photocatalytic process of $\mathrm{NO}$ removal over the $\mathrm{Sb}_{2} \mathrm{WO}_{6} / g-\mathrm{C}_{3} \mathrm{~N}_{4}$ nanocomposite occurred via an oxygen-induced route. This study demonstrated that the S-scheme $\mathrm{Sb}_{2} \mathrm{WO}_{6} / \mathrm{g}-\mathrm{C}_{3} \mathrm{~N}_{4}$ semiconductor is a promising photocatalyst for $\mathrm{NO}$ removal.

\section{References}

[1] F. Luck, J. Roiron, Catal. Today, 1989,4, 205-218.

[2] S. L. Fischer, C. P. Koshland, Environ. Sci. Technol., 2007, 4, 3121-3126.

[3] S. Matsuda, H. Hatano, Powder Technol., 2005, 151, 61-67.

[4] L. Jessica, P. Natan, V. Vitor, S. Cintia, J. Hazard. Mater., 2018, 327, 145-153.

[5] X. Feng, W. D. Zhang, Y. J. Sun, H. W. Huang, F. Dong, Environ. Sci. 
Nano, 2017, 4, 604-612.

[6] S. Wang, Y. Q. Zeng, Y. N. Wang, S. L. Zhang, Q. Zhong, T. X. Wang, X. M. Wang. Appl. Surf. Sci., 2019, 476, 834-839.

[7] M. X. Ran, J. R. Li, W. Cui, Y. H. Li, P. D. Li, F. Dong, Catal. Sci. Technol., 2018, 8, 3387-3394.

[8] Y. Hu, X. Song, S. M. Jiang, C. H. Wei, Chem. Eng. J., 2017, 274, 102-112.

[9] N. Todorova, T. Giannakopoulou, K. Pomoni, J. G. Yu, T. Vaimakis, C. Trapalis, Catal. Today, 2014, 252, 41-46.

[10] W. C. Huo, T. Cao, W. N. Xu, Z. Y. Guo, X. Y. Liu, H. C. Yao, Y. X. Zhang, F. Dong, Chin. J. Catal., 2020, 41, 268-275.

[11] J. Y. Zhang, Y. H. Wang, J. Jin, J. Zhang, Z. Lin, F. Huang, J. G. Yu, ACS Appl. Mater. Interfaces, 2013, 5, 10317-10324.

[12] J. W. Fu, Q. L. Xu, J. X. Low, C. J. Jiang, J. G. Yu, Appl. Catal. B, 2019, 243, 556-565.

[13] L. J. Xu, L.Y. Qi, Y. Sun, H. Gong, Y. L. Chen, C. Pei, L. Gan, Chin. J. Catal., 2020, 41, 322-332.

[14] F. F. Mei, Z. Li, K. Dai, J. F. Zhang, C.H. Liang, Chin. J. Catal., 2020, 41, 41-49.

[15] K. Z. Qi, W. X. Lv, I. Khan, S. Y. Liu, Chin. J. Catal., 2020, 41, 114-121.

[16] Q. Xie, W. M. He, S. W. Liu, C. H. Li, J. F. Zhang, P. K. Wong, Chin. J. Catal., 2020, 41, 140-153.

[17] B. Lin, S. Chen, F. Dong, G. D. Yang, Nanoscale, 2017, 9, 5273-5279.

[18] H. Wang, W. J. He, X. A. Dong, G. G. Jiang, Y. X. Zhang, Y. J. Sun, F. Dong, RSC Adv., 2017, 7, 19280-19287.

[19] Z. Wan, G. K. Zhang, J. Mater. Chem. A, 2015, 3, 16737-16745.

[20] X. J. Wen, C. G. Niu, L. Zhang, Appl. Catal. B, 2018, 221, 701-714.

[21] T. P. Hu, K. Dai, J. F. Zhang, G. P. Zhu, C. G. Liang, Mater. Lett., 2019, $257,126740$.

[22] F. F. Mei, K. Dai, J. F. Zhang, W. Y. Lia, C. H. Liang, Appl. Surf. Sci., 2019, 488, 151-160.

[23] X. B. Li, J. Xiong, Y. Xu, Z. J. Feng, J. T. Huang, Chin. J. Catal., 2019, 40, 424-433.

[24] P. F. Xia, S. W. Cao, B. C. Zhu, M. G. Liu, M. S. Shi, J. G. Yu, Y. F. Zhang, Angew. Chem. Int. Ed., 2020, 59, 5218-5225.

[25] Q. Yan, G. F. Huang, D. F. Li, M. Zhang, A. L. Pan, W. Q. Huang, J. Mater. Sci. Technol., 2018, 34, 2515-2520.

[26] K. Wang, G. K. Zhang, J. Li, Y. Li, X. Y. Wu, ACS Appl. Mater. Interfaces, 2017, 9, 43704-43715.

[27] G. M. Jiang, J. W. Cao, M. Chen, X. M. Zhang, F. Dong, Appl. Surf. Sci., 2018, 458, 77-85.
[28] R. Wang, J. Shen, W. J. Zhang, Q. Q. Liu, M. Y. Zhang, H. Tang, Ceram. Int., 2020, 46, 23-30.

[29] H. X. Fan, H. L. Zhou, W. J. Lia, S. N. Gu, G. W. Zhou, Appl. Surf. Sci., 2020, 504, 144351.

[30] Q. Yan, G. F. Huang, D. F. Li, M. Zhang, A. L. Pan, W. Q. Huang, J. Mater. Sci. Technol., 2018, 34, 2515-2520.

[31] M. Jourshabani, Z. Shariatini, A. Badiei, J. Mater. Sci. Technol., 2018, 34, 1511-1525.

[32] J. Wang, Q. Zhang, F. Deng, X. B. Luo, D. D. Dionysiou, Chem. Eng. J., 2020, 379, 122264.

[33] F. He, A. Y. Meng, B. Cheng, W. K. Ho, J. G. Yu, Chin. J. Catal., 2020, $41,9-20$.

[34] H. N. Ge, F. Y. Xu, B. Cheng, J. G.Yu, W. K. Ho, ChemCatChem, 2019, 11, 6301-6309.

[35] X. M. Jia, Q. F. Han, M. Y. Zheng, H. P. Bi, Appl. Surf. Sci., 2019, 489, 409-419.

[36] K. Wang, J. Li, G. K. Zhang, ACS Appl. Mater. Interfaces, 2019, 11, 27686-27696.

[37] F. Y. Xu, W. Xiao, B. Cheng, J. G. Yu, Int. J. Hydrogen Energy, 2014, 39, 15394-15402.

[38] P. Zhou, J. G Yu, M. Jaroniec, Adv. Mater., 2014, 26, 4920-4935.

[39] J. Zhang, Y. M. Dong, X. Liu, H. X. Li, Chem. J. Chinese U., 2019, 40, 123-129.

[40] K. Wang, Y. Li, J. Li, G. K. Zhang, Appl. Catal. B, 2020, 263, 117730.

[41] C. Y. Yang, X. J. Yang, F. Li, J. Ind. Eng. Chem., 2016, 39, 93-100.

[42] S. P. Hu, C. Y. Xu, F. X. Ma, Dalton Trans., 2014, 43, 8439-8445.

[43] Z. J. Zhang, X. Y. Chen, Mater. Sci. Eng. B, 2016, 209, 10-16.

[44] C. Q. Ding, Z. Q. Li, W. S. Tan, H. D. Li, J. F. Ma, Z. P. Chen, Y. X. Tao, Y. Qin, Y. Kong, Synth. Met., 2018, 246, 137-143.

[45] S. Q. Chen, M. Y. Zhou, T. H. Li, W. Cao, J. Mol. Liq., 2018, 272, 27-36.

[46] J. H. Bi, Y. Q. Liu, S. J. Liang, W. M. Wu, R. S. Yuan, L. Wu, J. Nanopart. Res., 2013, 15, 1661.

[47] M. Zhang, Z. Chen, J. T. Huang, S. Q. Wang, Q. M. Xiong, Z. J. Feng, Q. W. Liu, Z. H. Sun, X. B. Li, Ceram. Int., 2019, 45, 21923-21930.

[48] Y. J. Ren, D. Q. Zeng, W. J. Ong, Chin. J. Catal., 2019, 40, 289-319.

[49] U. Rafiq, K. Majid. J. Mater. Sci. Mater. Electron., 2019, 30, 5965-5977.

[50] S. C. Yan, Z. S. Li, Z. G. Zou, Langmuir, 2009, 25, 10397-10401.

[51] L. Liu, D. Ma, H, Zheng, Microporous Mesoporous Mater., 2008, 108, 216-222.

[52] D. Ma, J. Wu, M. C. Gao, Y. J. Xin, T. J. Ma, Y. Y. Sun, synth. Met., 2016, 290, 136-146.

\section{Graphical Abstract}

Chin. J. Catal., 2021, 42: 69-77 doi: 10.1016/S1872-2067(20)63631-2

\section{S-scheme $\mathrm{Sb}_{2} \mathrm{WO}_{6} / \mathrm{g}_{-} \mathrm{C}_{3} \mathrm{~N}_{4}$ photocatalysts with enhanced visible-light-induced photocatalytic NO oxidation performance}

Yuyu Ren, Yuan Li, Xiaoyong Wu, Jinlong Wang, Gaoke Zhang * Wuhan University of Technology

The S-scheme heterojunctions between $\mathrm{Sb}_{2} \mathrm{WO}_{6}$ and $\mathrm{g}_{-} \mathrm{C}_{3} \mathrm{~N}_{4}$ enhanced both the utilization of visible light and the separation of photoinduced electron-hole pairs.

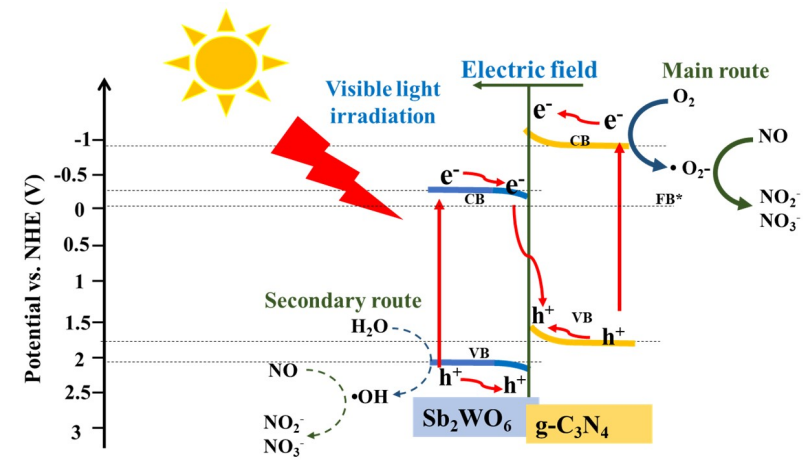


[53] W. J. Liao, M. Murugananthan, Y.R. Zhang, Phys. Chem. Chem. Phys., 2015, 17, 8877-8884.

[54] N. Nie, L. Y. Zhang, J. W. Fu, B. Cheng, J. G. Yu, Appl. Surf. Sci., 2018, $441,12-22$.

[55] Q. X. Guo, Y. Xie, X. J. Wang S. C. Lv, T. Hou, X. M. Liu, Chem. Phys. Lett., 2003, 380, 84-87.

[56] H. H. Ji, F. Chang, X. F. Hu, W. Qin, J. Shen, Chem. Eng. J., 2013, 218, 183-190.

[57] D. D. Tang, G. K. Zhang, Appl. Surf. Sci., 2017, 391, 415-422.

[58] J. Wang, D. Feng, W. Wu, M. Zeng, Y. Li, Polym. Degrad. Stab., 1991, $31,129-140$.

[59] D. Sun, Y. Le, C. J. Jiang, B. Cheng, Appl. Surf. Sci., 2018, 441, 429-437.

[60] X. L. Liu, H. Y. Li, J. J. Ma, Mol. Catal., 2019, 466, 157-166.

[61] H. Tang, K. P. Dou, C. C. Kaun, Q. Kuang, S. H. Yang, J. Mater. Chem. $A$, 2014, 2, 360-364.

[62] Y. Li, X. Y. Wang, J. Gong, Y. H. Xie, X. Y. Wu, G. K. Zhang, ACS Appl.
Mater. Interfaces, 2018, 10, 43760-43767.

[63] X. F. Yang, L. Tian, X. L. Zhao, H. Tang, Q. Q. Liu, G. S. Li, Appl. Catal. $B, 2019,244,240-249$.

[64] Y. H. Li, K. L. Lv, W. K. Ho, F. Dong, X. F. Wu, Y. Xia, Appl. Catal. B, 2017, 202, 611-619.

[65] F. Dong, Z. Wang, Y. Sun, W. K. Ho, H. Zhang, J. Colloid Interface Sci., 2013, 401, 70-79.

[66] H. Wei, W. A. McMaster, J. Z. Y. Tan, L. Cao, D. Chen, R. A. Caruso, J. Phys. Chem. C., 2017, 121, 22114-22122.

[67] M. Li, H. Huang, S. Yu, N. Tian, F. Dong, X. Du, Y. Zhang, Appl. Surf. Sci., 2016, 386, 285-295.

[68] T. Sano, S. Tsutsui, K. Koike, T. Hirakawa, Y. Teramoto, N. Negishi, K. Takeuchi, J. Mater. Chem. A, 2013, 1, 6489-6496.

[69] F. Dong, R. Wang, X. Li, W. K. Ho, Appl. Surf. Sci., 2014, 319, 256-264.

[70] J. Arañ, D. Garzón Sous, O. González Díaz, E. Pulido Melián, J. M. Doña Rodríguez, Appl. Catal. B, 2019, 244, 660-670.

\title{
$\mathrm{S}_{\text {型 }} \mathrm{Sb}_{2} \mathrm{WO}_{6} / \mathrm{g}-\mathrm{C}_{3} \mathrm{~N}_{4}$ 复合光催化剂及其增强的可见光诱导的光催化氧化NO性能
}

\author{
任雨雨 ${ }^{\dagger}$, 李 源”，吴晓勇，王金龙，张高科 ${ }^{*}$ \\ 武汉理工大学矿物资源加工与环境湖北省重点实验室, 硅酸盐建筑材料国家重点实验室, 湖北武汉 430070
}

\begin{abstract}
摘要: 近年来, 随着工业化和城镇化的飞速发展, 作为一种典型的空气污染物, $\mathrm{NO}_{x}$ 已经造成严重的环境问题, 甚至威胁到 人类的身体健康. 为了解决这个问题, 科研工作者研发了许多 $\mathrm{NO}_{x}$ 去除技术, 其中光催化技术被认为是一种能有效地去除 空气中 $\mathrm{NO}_{x}$ 的技术. 作为一种廉价、无毒、热稳定性强、能带结构合适的光催化材料, 石墨相氮化碳 $\left(\mathrm{g}-\mathrm{C}_{3} \mathrm{~N}_{4}\right)$ 能够有效的利 用可见光, 将 $\mathrm{NO}$ 光催化氧化为 $\mathrm{NO}_{3}^{-}$. 但是由于自身的光生载流子复合率较高, 光谱响应范围较窄等缺点, $\mathrm{g}-\mathrm{C}_{3} \mathrm{~N}_{4}$ 不能有效 的光催化去除空气中持续流动的低浓度 $\mathrm{NO}$, 限制了其在光催化领域中的实际应用. 因此, 有必要合成出高催化活性、高光 响应范围的 $\mathrm{S}$ 型复合光催化剂来克服以上光催化材料的不足. 为此, 我们利用超声辅助法制备了一系列的 $\mathrm{S}$ 型 $\mathrm{Sb}_{2} \mathrm{WO}_{6} / \mathrm{g}-\mathrm{C}_{3} \mathrm{~N}_{4}$ 复合光催化剂, 呈现出优异的光催化活性: 与其纯组分相比, 所制备的 $15-\mathrm{Sb}_{2} \mathrm{WO}_{6} / \mathrm{g}-\mathrm{C}_{3} \mathrm{~N}_{4}$ 复合光催化剂在 可见光下照射 $30 \mathrm{~min}$, 可去除 $68 \%$ 以上的持续流动的 $\mathrm{NO}$ (初始浓度 $400 \mathrm{ppb}$ ), 且五次循环实验后, $\mathrm{Sb}_{2} \mathrm{WO}_{6} / \mathrm{g}-\mathrm{C}_{3} \mathrm{~N}_{4}$ 复合光催化 剂仍然具备良好的光催化活性和稳定性. 透射电子显微镜结果清楚地表明, $\mathrm{Sb}_{2} \mathrm{WO}_{6}$ 颗粒已成功地均匀地负载到 $\mathrm{g}-\mathrm{C}_{3} \mathrm{~N}_{4}$ 纳 米片表面. 紫外可见漫反射光谱的结果表明, $\mathrm{Sb}_{2} \mathrm{WO}_{6}$ 和 $\mathrm{g}-\mathrm{C}_{3} \mathrm{~N}_{4}$ 的复合可以有效地提高对可见光的吸收能力. 与纯 $\mathrm{g}-\mathrm{C}_{3} \mathrm{~N}_{4}$ 样 品相比, 复合样的吸收带边具有明显的红移. 光致发光光谱结果表明, 在 $\mathrm{Sb}_{2} \mathrm{WO}_{6} / \mathrm{g}-\mathrm{C}_{3} \mathrm{~N}_{4}$ 复合半导体中, 光生载流子的复合 受到抑制. 光电流与电阻抗分析可知, 与纯 $\mathrm{Sb}_{2} \mathrm{WO}_{6}$ 和 $\mathrm{g}-\mathrm{C}_{3} \mathrm{~N}_{4}$ 相比较, 在 $15-\mathrm{Sb}_{2} \mathrm{WO}_{6} / \mathrm{g}-\mathrm{C}_{3} \mathrm{~N}_{4}$ 复合光催化剂中的光生载流子的 迁移速率和分离效率较高. 通过对样品的能带结构分析并已有参考文献, 我们认为 $\mathrm{Sb}_{2} \mathrm{WO}_{6}$ 和 $\mathrm{g}-\mathrm{C}_{3} \mathrm{~N}_{4}$ 的接触边界形成了 $\mathrm{S}$ 型 异质结, 使光生载流子的转移速率更快, 改善了光生电子-空穴对分离, 而且增强可见光的利用效率, 从而提高了光催化性 能. 自由基捕获实验结果证实, $\cdot \mathrm{O}_{2}{ }^{-}$主导了 $\mathrm{Sb}_{2} \mathrm{WO}_{6} / \mathrm{g}-\mathrm{C}_{3} \mathrm{~N}_{4}$ 复合光催化剂去除 $\mathrm{NO}$ 反应, $\mathrm{h}^{+}$也在一定程度上参与了光催化氧 化 $\mathrm{NO}$ 的反应. 通过原位红外光谱技术研究了 $\mathrm{Sb}_{2} \mathrm{WO}_{6} / \mathrm{g}-\mathrm{C}_{3} \mathrm{~N}_{4}$ 光催化 $\mathrm{NO}$ 氧化的反应机理, 研究发现, $\mathrm{Sb}_{2} \mathrm{WO}_{6} / \mathrm{g}-\mathrm{C}_{3} \mathrm{~N}_{4}$ 复合光 催化剂光催化去除是氧诱导的反应. 具体反应机理是在可见光的驱动下, 光催化剂表面的光生电子会与被吸附的 $\mathrm{O}_{2}$ 反应 生成 $\cdot \mathrm{O}_{2}^{-}$, 并与光生 $\mathrm{h}^{+}$一起, 共同将低浓度的 $\mathrm{NO}$ 光催化氧化为亚硝酸盐或硝酸盐. 该研究有助于深入研究光催化氧化 $\mathrm{NO}$ 机 理, 并为设计高效光催化剂用于光催化氧化ppb级NO提供了一种极具前景的策略.
\end{abstract}

关键词: 钨酸锑; 石墨相 $\mathrm{C}_{3} \mathrm{~N}_{4}$; $\mathrm{S}$ 型光催化剂; 光催化去除氮氧化物; 原位红外测试

收稿日期: 2020-03-16. 接受日期: 2020-04-30. 出版日期: 2021-01-05.

*通讯联系人. 电话: (027)87651816; 传真: (027)87887445; 电子信箱: gkzhang@whut.edu.cn

†共同第一作者.

基金来源：国家自然科学基金(51472194); 湖北省自然科学基金(2016CFA078).

本文的电子版全文由Elsevier出版社在ScienceDirect上出版(http://www.sciencedirect.com/science/journal/18722067). 